\title{
KESUBURAN PERAIRAN DITINJAU DARI KANDUNGAN KLOROFIL-A FITOPLANKTON: STUDI KASUS DI SUNGAI WEDUNG, DEMAK
}

\author{
Nabila Ghassani Adani, Max Rudolf Muskanonfola, Ignatius Boedi Hendrarto ${ }^{\text {I }}$ \\ Program Studi Manajemen Sumberdaya Perairan, Jurusan Perikanan \\ Fakultas Perikanan dan Ilmu Kelautan, Universitas Diponegoro
}

\begin{abstract}
ABSTRAK
Perairan Sungai Wedung merupakan ekosistem pesisir yang banyak dimanfaatkan untuk berbagai kegiatan manusia. Hal tersebut tentunya berpengaruh terhadap kesuburan perairan Sungai Wedung. Kesuburan di perairan tersebut dipengaruhi oleh plankton, faktor kimia, fisika dan juga kandungan KlorofilA. Pengukuran kandungan klorofil-a fitoplankton merupakan salah satu alat pengukuran kesuburan suatu perairan. Klorofil-a fitoplankton adalah suatu pigmen aktif dalam sel tumbuhan yang mempunyai peran penting dalam berlangsungnya proses fotosintesis perairan. Penelitian dilakukan pada bulan April - Mei 2013 di Sungai Wedung, Demak bertujuan untuk mengetahui aktivitas manusia terhadap sebaran klorofil-a, keterkaitan antara klorofil-a dan kelimpahan fitoplankton dan tingkat kesuburan perairan berdasarkan kandungan klorofil-a fitoplankton. Metode yang digunakan adalah metode studi kasus dengan teknik pengambilan sampel menggunakan metode "Sample Survey Method". Hasil penelitian menunjukkan bahwa hasil analisis data klorofil menggunakan metode anova tersarang (nested anova) diperoleh nilai $\mathrm{P}$ untuk stasiun cukup besar sehingga tidak memberikan perbedaan yang nyata pada taraf kepercayaan $95 \%$. Akan tetapi perbedaan akan nyata pada taraf $90 \%$. Hubungan antara klorofil-a dengan kelimpahan fitoplankton secara linear menunjukkan nilai keeratan yang tinggi dengan nilai koefisien korelasi sebesar 0,93 dan koefisien determinasi sebesar 0,8633 dimana 86\% klorofil-a dipengaruhi oleh kelimpahan fitoplankton. Berdasarkan nilai rata-rata klorofil-a yang diperoleh sebesar 1,039863 mg/l dapat disimpulkan bahwa perairan Sungai Wedung tergolong kedalam perairan yang bersifat oligotrofik.
\end{abstract}

Kata Kunci: Klorofil-a, Fitoplankton, Kesuburan Perairan, Sungai Wedung

\section{ABSTRACT}

The waters of the river Wedung is a coastal ecosystem much utilized for a variety of human activities. It would surely affect the fertility of the waters of the river Wedung. The fertility of the waters affected by plankton, chemistry, physics and also the content of Chlorophyll-A. Measurement of content of chlorophyll-a phytoplankton measurement tool is one of the fertility of the waters. Chlorophyll-a phytoplankton is a pigment in the plant cell, which has an important role in the continuation of the process of photosynthesis. Research conducted in April - May 2013 on the river Wedung, Demak aims to know human activity towards the distribution of chlorophyll-a, the link between chlorophyll-a and phytoplankton abundance and fertility rates based on chlorophyll content of waters-a phytoplankton. The method used is the method of case studies with the techniques of sampling method using "Sample Survey Method". The results showed that chlorophyll data analysis results using the method of nested anova obtained the value of $\mathrm{P}$ for the station is large enough so that it does not provide any noticeable difference in the degrees of confidence of $95 \%$. But the difference will be noticeable in the extent of $90 \%$. Relationship between chlorophyll-a and phytoplankton abundance linearly shows the value of keeratan with a high correlation coefficients of determination of coefficients of 0.93 and 0,8633 where $86 \%$ of the chlorophyll-a was influenced by the abundance of phytoplankton. Based on the average value of chlorophyll-a was obtained by 1,039863 mg/l can be inferred that the waters of the river Wedung into waters that are classified as oligotrofik.

Keywords : Chlorophyll - a, phytoplankton, Fertility Waters, River Wedung 


\section{PENDAHULUAN}

Sungai merupakan sumber air permukaan yang memberikan manfaat kepada kehidupan manusia. Dari mata air sebagai awal mengalirnya air, melintasi bagian-bagian alur sungai hingga ke bagian hilir yang terjadi secara dinamis. Kedinamisan tersebut tergantung dari musim, karakteristik alur sungai, dan pola hidup manusia disekitarnya. Kondisi ini menyebabkan baik kuantitas maupun kualitasnya akan mengalami perubahan-perubahan sesuai dengan perkembangan lingkungan sungai dan kehidupan manusia (Sukadi,1999).

Fitoplankton adalah golongan plankton yang mempunyai klorofil di dalam tubuhnya. Daerah hidup fitoplankton adalah di lapisan yang masih dapat terkena sinar matahari. Fitoplankton dapat membuat makanannya sendiri dengan mengubah bahan anorganik menjadi bahan organik melalui proses fotosintesis dengan menggunakan bantuan sinar matahari (Mulyanto 1992).

Klorofil-a fitoplankton adalah suatu pigmen aktif dalam sel tumbuhan yang mempunyai peranan penting di dalam proses berlangsungnya fotosintesis diperairan. Semua sel berfotosintesis mengandung satu atau beberapa pigmen berklorofil (hijau coklat, merah atau lembayung), sementara itu dalam mata rantai makanan (food chain) di perairan, fitoplankton mempunyai fungsi sebagai produsen primer dimana organisme ini mampu mengubah bahan anorganik menjadi bahan organik melalui proses fotosintesis, untuk itu maka kandungan klorofil-a digunakan sebagai standing stock fitoplankton yang dapat dijadikan produktivitas primer suatu perairan (Pugesehan, 2010).

Sungai Wedung merupakan salah satu sungai yang berada di Kabupaten Demak. Sungai Wedung ini banyak dimanfaatkan oleh kegiatan manusia, antara lain yaitu lalu lintas kapal nelayan, tempat sandar kapal nelayan, pembuangan limbah masyarakat. Kegiatan manusia tersebut berpengaruh terhadap kesuburan perairan Sungai Wedung. Kesuburan di perairan tersebut dipengaruhi oleh plankton, faktor kimia, fisika dan juga kandungan Klorofil-a.

Kandungan pigmen fotosintesis (terutama klorofil-a) dalam air sampel menggambarkan biomassa fitoplankton dalam suatu perairan. Klorofil-a merupakan pigmen yang selalu ditemukan dalam fitoplankton dan merupakan pigmen yang terlibat langsung dalam proses fotosintesis. Jumlah klorofil-a pada setiap individu fitoplankton tergantung pada jenis fitoplankton, oleh karena itu komposisi jenis fitoplankton sangat berpengaruh terhadap kandungan klorofil-a di perairan. Penelitian mengenai kandungan klorofil-a fitoplankton untuk melihat kesuburan perairan perlu dilakukan karena belum pernah diadakan penelitian di perairan tersebut dan untuk melihat sejauh mana kondisi kualitas perairan Sungai Wedung.

\section{MATERI DAN METODE PENELITIAN}

\section{A. Materi Penelitian}

Materi yang digunakan dalam penelitian di Sungai Wedung terdiri dari dua variabel yang telah ditentukan, yaitu varibel utama dan variabel pendukung. Variabel utama terdiri dari jenis-jenis fitoplankton, kelimpahan fitoplankton dan klorofil-a. Variabel penunjang yang juga diteliti antara lain kedalaman, kecerahan, suhu, arus, $\mathrm{pH}$ dan DO.

Alat yang digunakan saat sampling lapangan yaitu ember plastik untuk mengambil sampel air, botol 1,5 liter untuk mengambil sampel klorofil-a, botol $100 \mathrm{ml}$ untuk menyimpan sampel plankton, plankton net untuk menjaring fitoplankton, cool box untuk menyimpan sampel air, es batu untuk menjaga suhu air sampel stabil, kertas label untuk memberi tanda pada sampel, stopwatch, kamera digital untuk dokumentasi dan alat tulis untuk mencatat data yang diperoleh. Alat yang digunakan pada saat pengukuran kualitas air yaitu termometer untuk mengukur suhu, secchi disk untuk mengukur kecerahan serta kedalaman, DO meter untuk mengukur kadar oksigen terlarut, refraktometer untuk mengukur besarnya salinitas dan $\mathrm{pH}$ paper untuk mengetahui nilai $\mathrm{pH}$ di perairan dan bola arus untuk mengukur kecapatan arus. Alat yang digunakan pada saat identifikasi di laboratorium yaitu mikroskop, serta sedgewick rafter untuk mencacah fitoplankton dalam pengamatan. Alat yang digunakan dalam pengukuran klorofil adalah sentrifuge untuk mengendapkan kertas saring agar tisak tercampur dengan sampel klorofil-a, spektrofotometer untuk mengukur kandungan klorofila, vacuum pump untuk menyaring sampel klorofil. Filtering flask untuk menampung hasil penyaringan sampel klorofil, corong untuk menyaring sampel air, botol reaksi untuk tempat sampel yang akan diukur pada spektrofotometer.

Bahan yang digunakan dalam penelitian ini adalah sampel air dan plankton yang didapat dari perairan Sungai Wedung, es batu untuk mengawetkan sampel air pada coolbox, serta lugol iodine untuk pengawetan sampel, aseton $90 \%$ untuk mengekstrak sampel klorofil-a, kertas saring whatman untuk menyaring sampel klorofil, aquades untuk kalibrasi.

\section{B. Metode Penelitian}

Metode yang digunakan pada penelitian menggunakan metode studi kasus yang merupakan suatu metode yang mempelajari objek secara mendalam pada waktu, tempat dan populasi yang terbatas sehingga informasi yang diperoleh hanya bersifat lokal dan hasilnya tidak berlaku untuk tempat dan waktu yang berbeda. (Hermawan, 2007). 


\section{Penentuan lokasi sampling}

Lokasi pengambilan sampel dilakukan secara purposive yaitu pengambilan data dengan alasan dan pertimbangan tertentu dengan sengaja untuk mendapatkan sampel yang mewakili baik area maupun kelompok sampel sehingga didapat gambaran lokasi penelitian secara keseluruhan.

Lokasi pengambilan sampel dilakukan di Sungai Wedung. Pengambilan sampel dilakukan pada 3 stasiun, dimana setiap stasiun mewakili keadaan suatu lokasi, jarak antar stasiun penelitian adalah $500 \mathrm{~m}$. Stasiun I terletak di koordinat $06^{\circ} 47^{\prime} 42,54^{\prime \prime} \mathrm{LS}$ dan $110^{\circ} 37^{\prime} 6,87^{\prime}$ BT, lokasi ini merupakan bagian sungai yang berada persis setelah bendungan. Pada stasiun II terdapat pasar dan di pinggir kanan dan kiri sungai digunakan sebagai tempat sandar perahu nelayan dengan koordinat $06^{\circ} 47^{\prime} 36,93^{\prime}$ 'LS dan $110^{\circ} 36^{\prime} 48,30$ BT. Pada stasiun III terletak di koordinat $06^{\circ} 47^{\prime} 28,44^{\prime \prime} \mathrm{LS}$ dan $110^{\circ} 36^{\prime} 34,41$ BT, lokasi ini terletak setelah TPI dan di sekitarnya terdapat mangrove.

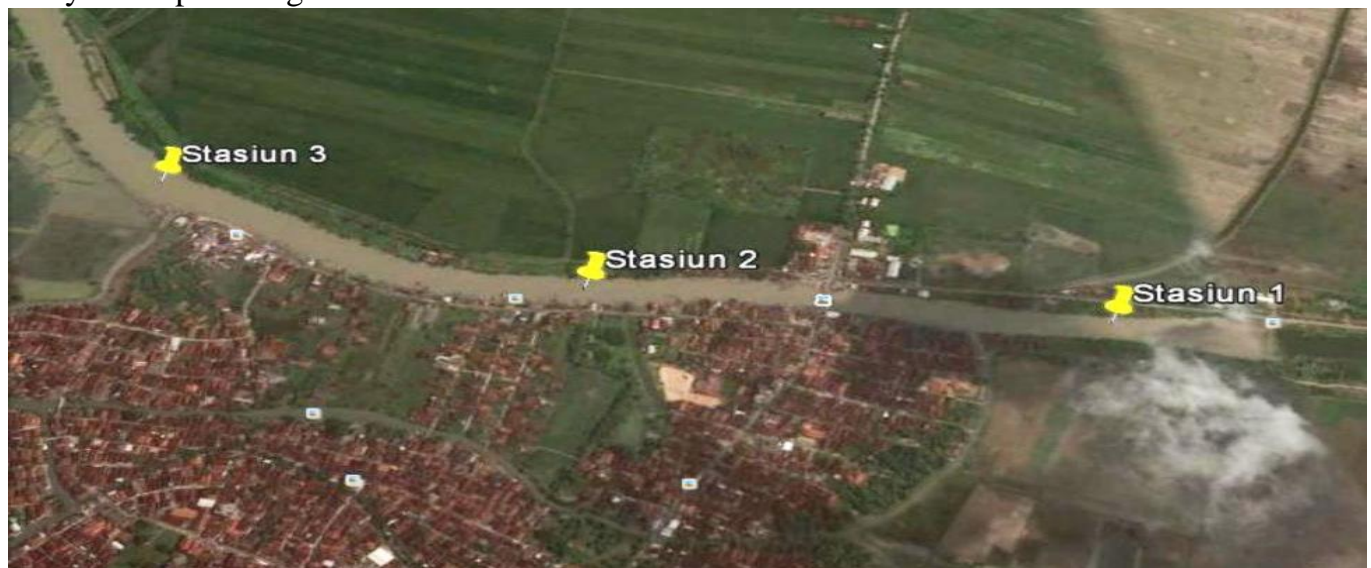

Gambar 1. Lokasi Sampling

\section{Pengambilan sampel}

Untuk teknik pengambilan sampel dalam penelitian ini menggunakan metode penelitian sampel "(Sample Survey Method)". Metode penelitian sampel adalah metode pengambilan sampel dengan mengambil data hanya sebagian dari populasi yang nantinya diharapkan dapat menggambarkan sifat populasi dari obyek penelitian (Hadi, 1998).

Pengambilan sampel plankton dilakukan menggunakan metode penyaringan (filtration method). Metode ini dilakukan dengan mengambil 100 liter air di perairan kemudian disaring menggunakan plankton net bermesh size $25 \mathrm{~nm}$. Hasil penyaringan plankton di simpan pada botol sampel $100 \mathrm{ml}$ dan diberi 2 - 3 tetes lugol iodine untuk mengawetkan sampel plankton.

Tiap stasiun ditentukan sembilan titik untuk mengetahui kandungan klorofil-a, kemudian dilakukan pengambilan sampel klorofil secara horizontal pada badan air. Setelah itu sampel klorofil yang telah diambil disimpan pada coolbox yang telah diberi es batu. Pengukuran variabel penunjang diukur secara insitu pada badan air di lokasi penelitian.

Desain sampling menggunakan desain tersarang, dimana dalam percobaan multifaktor tertentu jika subsampel pertama dari perlakuan A ( nomor 1 dalam bagan dibawah) yang serupa tapi tidak identik dengan subsampel pertama dari perlakuan B ( nomor 4 dalam bagan dibawah ). Maka, untuk menekankan bahwa antar subsampel adalah berbeda maka kita dapat memberikan nomor baru subsampel dengan 1, 2, 3 dari perlakuan A; 4, 5, 6 dari perlakuan $\mathrm{B}$; dan 7, 8, 9, dari perlakuan $\mathrm{C}$.

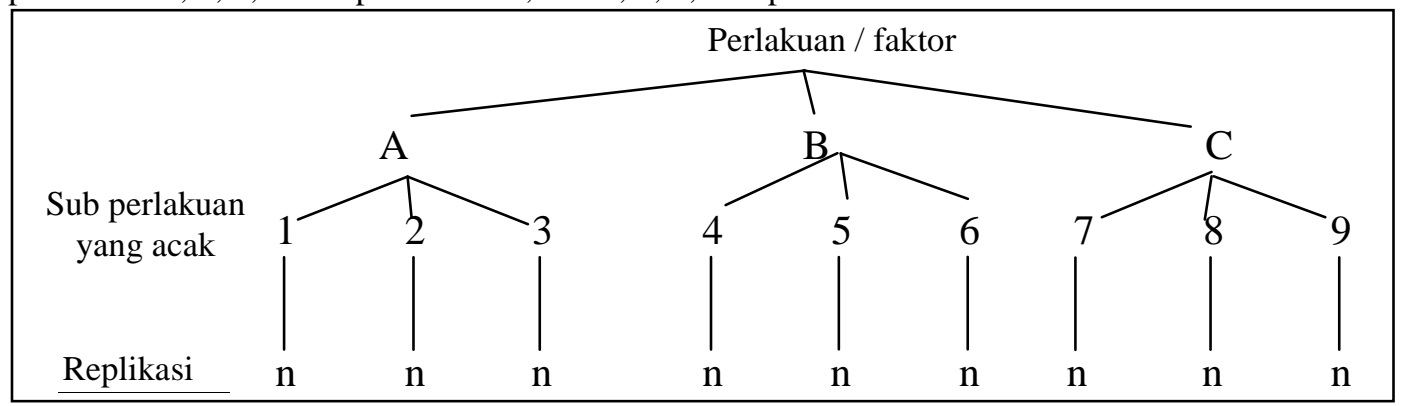

Gambar 2. Desain sampling

\section{Pengukuran klorofil-a}

Sampel air sebanyak $1500 \mathrm{ml}$ yang telah diambil disaring dengan kertas saring Whatman GF/C 42 $\mu \mathrm{m}$ dengan diameter $47 \mathrm{~mm}$, kertas saring kemudian dimasukkkan kedalam botol kaca tertutup yang berisi 15 $\mathrm{ml}$ larutan aseton 90\%. Botol sampel disimpan pada suhu $4^{\circ} \mathrm{C}$ selama $12-14$ jam. Larutan yang keruh 
kemudian diputar dalam sentrifuge dengan kecepatan 5300 rpm selama 2 × 5 menit sehingga larutan menjadi jernih dan endapannya terkumpul di dasar. Selanjutnya dianalisis dengan spektrofotometer.

\section{Pengukuran variabel penunjang}

Pada masing-masing stasiun penelitian juga dilakukan pengamatan variabel penunjang. Pengukuran parameter perairan tersebut dilakukan secara insitu yang meliputi suhu menggunakan termometer, kecerahan dan kedalaman menggunakan secchi disk, $\mathrm{pH}$ menggunakan $\mathrm{pH}$ paper, kandungan oksigen terlarut perairan dengan menggunakan DO meter.

\section{Perhitungan konsentrasi klorofil-a}

Perhitungan konsentrasi klorofil-a dilakukan dengan mengukur absorbansi pada panjang gelombang 664, 647 dan $630 \mathrm{~nm}$.

Perhitungan klorofil dihitung dengan rumus yang dikemukakan oleh Parsons et al. (1984), sebagai berikut:

\section{Keterangan:}

$$
\text { Klorofil }(\mathbf{m g} / \mathbf{l})=\frac{\text { Ca } \times \text { Va }}{\text { V x d }}
$$

$\mathrm{Va} \quad=$ volume aseton $(\mathrm{ml})$

$V \quad=$ volume sampel air yang disaring $(\mathrm{ml})$

$\mathrm{d} \quad=$ diameter cuvet

$\mathrm{Ca} \quad=\left(11.85 \times \mathrm{E}_{664}\right)-\left(1,54 \times \mathrm{E}_{647}\right)-\left(0,08 \times \mathrm{E}_{630}\right)$

$\mathrm{E} \quad=$ absorbansi pada panjang gelombang yang berbeda (yang dikoreksi dengan panjang gelombang $750 \mathrm{~nm}$ )

\section{Identifikasi fitoplankton}

Pengamatan dan perhitungan fitoplankton dilakukan dengan bantuan sedgewick rafter dan mikroskop, sedangkan pengidentifikasian plankton dengan menggunakan buku identifikasi Sachlan (1982). Setelah dilakukan identifikasi jenis-jenis plankton dilakukan perhitungan untuk mencari nilai kelimpahan jenis.

\section{Kelimpahan plankton}

Perhitungan kelimpahan fitoplankton per liter dilakukan dengan menggunakan formulasi APHA (1992), yaitu :

Keterangan:

$$
\mathbf{N}=\frac{T}{\mathbf{L}} \times \frac{\mathbf{P}}{\mathbf{p}} \times \frac{\mathbf{V}}{\mathbf{V}} \times \frac{\mathbf{1}}{\mathbf{W}}
$$

$$
\begin{array}{ll}
\mathrm{N} & =\text { jumlah plankton per liter } \\
\mathrm{T} & =\text { luas total petak Sedgewick rafter }\left(1000 \mathrm{~mm}^{2}\right) \\
\mathrm{L} & =\text { luas lapang pandang mikroskop }\left(\mathrm{mm}^{2}\right) \\
\mathrm{P} & =\text { jumlah plankton tercacah } \\
\mathrm{p} & =\text { jumlah lapang pandang yang diamati } \\
\mathrm{V} & =\text { volume sampel plankton yang tersaring }(\mathrm{ml}) \\
\mathrm{V} & =\text { volume sampel plankton dalam sedgewick rafter }(\mathrm{ml}) \\
\mathrm{W} & \text { =volume sampel air yang tersaring }(\mathrm{L})
\end{array}
$$

Karena sebagian dari unsur-unsur rumus tersebut telah diketahui pada sedgewick rafter, seperti $\mathrm{T}=1000 \mathrm{~mm}^{2}, \mathrm{v}=1 \mathrm{ml}$ dan $\mathrm{L}=0,25 \pi \mathrm{mm}^{2}$ (dimisalkan satu lingkaran sama dengan luas lapang pandang pada mikroskop dengan $\mathrm{r}=0,5 \mathrm{~mm}$ ), sehingga formulasinya dapat dibuat sebagai berikut :

$$
\mathrm{N}(\text { ind } / \mathrm{L})=\frac{100(\mathrm{P} \times \mathrm{V})}{0,25 \pi \mathrm{W}}
$$

\section{Regresi linear sederhana}

Analisis korelasi adalah mencoba mengukur kekuatan hubungan antara dua peubah, yaitu $\mathrm{x}$ dan $\mathrm{y}$ melalui sebuah bilangan yang disebut koefisien korelasi, dilambangkan dengan $r$. Nilai $r$ mengukur sejauh mana titik-titik menggerombol sekitar sebuah garis lurus. Berikut ini adalah rumus persaman regresi (Walpole, 1995) :

$$
y=a+b x
$$

Keterangan:

$\mathrm{y}=$ peubah tak bebas [klorofil-a $(\mathrm{mg} / \mathrm{l})]$

$\mathrm{x}=$ peubah bebas [kelimpahan fitoplankton(sel/l)]

$\mathrm{a}=$ intersep atau perpotongan dengan sumbu tegak

$\mathrm{b}=$ kemiringan atau gradient 


\section{Anova tersarang (Nested Anova)}

Anova Tersarang (Nested Anova). Anova ini digunakan untuk menguji data tiap perlakuan dibagi menjadi beberapa subsampel, dalam hal ini kita hanya menekankan hanya kepada kasus dimana tiap perlakuan dibagi menjadi subsampel yang jumlahnya sama dan semua subsampel memiliki jumlah observasi yang sama pula.

Model matematis untuk anova tersarang :

Keterangan

$$
X=m+t+s+r
$$

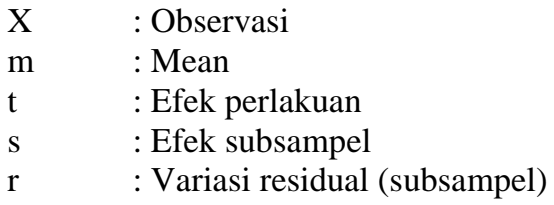

\section{HASIL DAN PEMBAHASAN}

\section{Deskripsi lokasi}

Lokasi penelitian berada di perairan Sungai Wedung yang terletak di wilayah Dusun Angin-angin Desa Buko Kecamatan Wedung, Kabupaten Demak. Desa Buko memiliki luas wilayah sebesar 658,960 Ha dengan jumlah penduduk \pm 4.918 jiwa dan sebagian besar penduduknya adalah nelayan.

Secara geografis, Desa Buko dibatasi oleh:

1. Sebelah Utara adalah Desa Berahan Wetan dan Desa Bungo

2. Sebelah Selatan adalah Desa Ngawen dan Desa Wedung

3. Sebelah Timur adalah Desa Kenduren dan Desa Rawit

4. Sebelah Barat adalah Desa Mandung dan Desa Berahan Kulon

\section{Klorofil-a}

Hasil pengukuran klorofil-a selama pengamatan dapat dilihat pada gambar 3. Kandungan klorofil-a pada paling tinggi pada stasiun 1 terletak pada titik 3 sebesar 1,388 mg/l, stasiun 2 sebesar 1,334 mg/l pada titik 9 dan stasiun 3 sebesar $1,273 \mathrm{mg} / \mathrm{l}$.

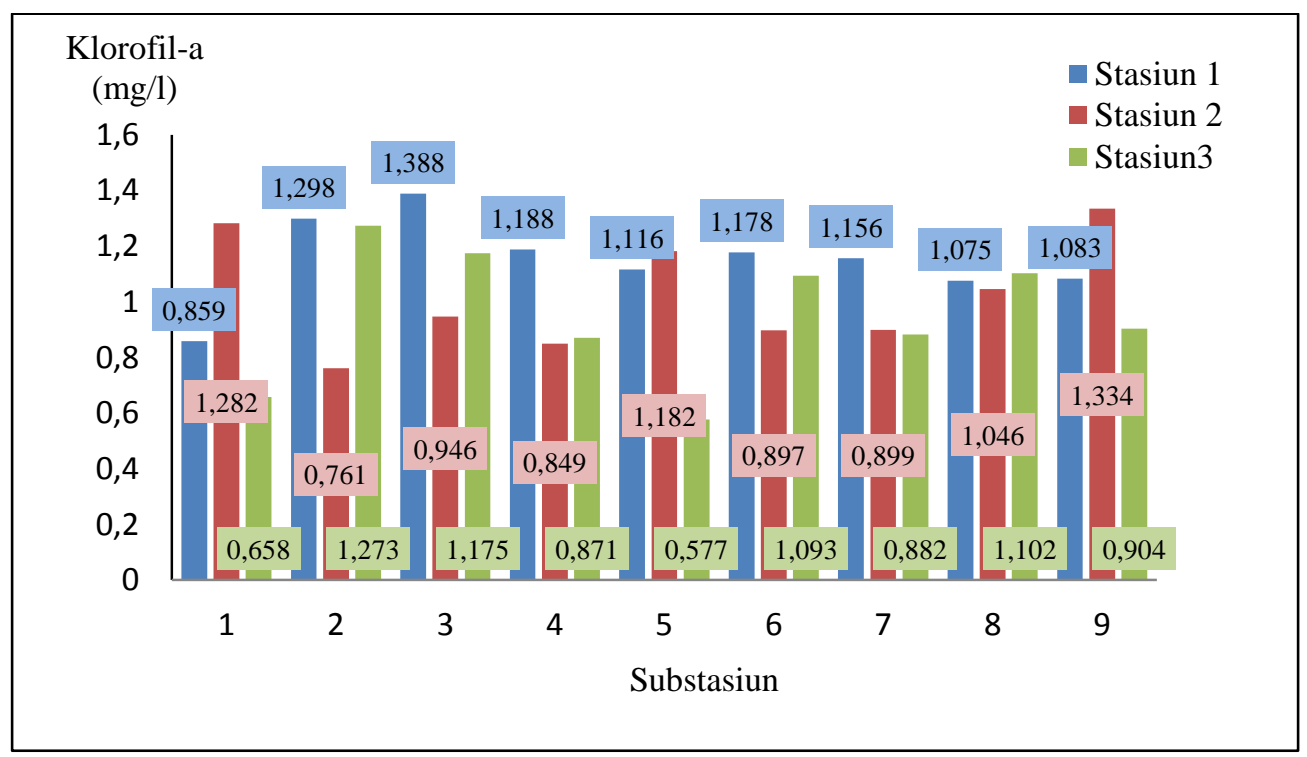

Gambar 3. Histogram Nilai Klorofil-a

Hasil analisa menunjukkan terdapat perbedaan yang nyata antara ketiga stasiun penelitian. Berdasarkan uji statistik dengan menggunakan metode tersarang, maka dapat dinyatakan bahwa klorofil-a antar stasiun penelitian $90 \%$ berbeda nyata. Dalam hal ini terdapat $10 \%$ ketidaksesuaian dari asumsi perbedaan tersebut.

Klorofil-a tertinggi terletak pada stasiun I sebesar $1,149152 \mathrm{mg} / \mathrm{l}$. Stasiun I terletak setelah bendungan dan belum terdapat aktivitas manusia yang signifikan dan di kanan kiri belum banyak terdapat rumah-rumah penduduk. Klorofil-a terendah terletak pada stasiun III sebesar 0,94865 mg/l. Stasiun III terletak setelah TPI dan sudah terdapat aktivitas manusia yaitu TPI dan juga pada stasiun II terdapat pasar, sandar kapal pada sisi tepi sungai. 
Rendahnya klorofil-a di lokasi penelitian disebabkan oleh faktor dari dalam tubuh plankton itu sendiri. Hal ini telah diteliti oleh Tambaru (2008) di Muara Sungai Tallo, tercatat bahwa rata-rata konsentrasi klorofil-a sekitar $0,2 \mathrm{mg} / \mathrm{l}$.

Menurut Widyorini (2009), hasil penelitian di Bandengan dan Pulau Panjang menunjukkan bahwa kandungan klorofil-a pada kedua lokasi termasuk rendah dengan nilai rata-rata $0,593 \mathrm{mg} / \mathrm{l}$ (Bandengan) dan $0,579 \mathrm{mg} / \mathrm{l}$ (Pulau Panjang).

Hasil penelitian Barus (2004), terdapat perbedaan kandungan klorofi a pada perairan tawar, keadaan ini berkaitan kondisi masing-masing perairan dan proses percampuran air dari bawah ke atas. Dari hasil penelitian diketahui bahwa untuk menguraikan senyawa organik yang terdapat dalam limbah rumah tangga secara sempurna, mikroorganisme membutuhkan waktu sekitar 20 hari. Variabel penunjang yang telah didapatkan selama penelitian di Sungai Wedung dapat dilihat pada tabel 1.

Tabel 1. Parameter Fisika Kimia di Sungai Wedung Demak

\begin{tabular}{cccc}
\hline Parameter & \multicolumn{3}{c}{ Stasiun } \\
\cline { 2 - 4 } & 1 & 2 & 3 \\
\hline Fisika & 3 & & 2 \\
Kedalaman $(\mathrm{cm})$ & $28.27-45.67$ & $28.5-46.67$ & $27,06-47.06$ \\
Kecerahan $(\mathrm{cm})$ & $30.27-33.04$ & $30.24-32.24$ & $30.17-32.48$ \\
Suhu $\left({ }^{\circ} \mathrm{C}\right)$ & $0.11-0.14$ & $0.09-0.25$ & $0.07-0.29$ \\
Arus (m/s) & & & \\
\hline Kimia $\quad$ DO & $1.37-6.65$ & $1.46-5.48$ & $1.65-5.92$ \\
pH & $7-8$ & $7-8$ & $7-8$ \\
\hline
\end{tabular}

Kedalaman pada lokasi penelitian berkisar antara $2-3 \mathrm{~m}$, kecerahan perairan antara $27-47 \mathrm{~cm}$. Kedalaman dan kecerahan akan mempengaruhi penetrasi sinar matahari kedalam perairan. Zat-zat terlarut dalam perairan mempengaruhi kecerahan yang berhubungan dengan penetrasi sinar matahari. Makin tinggi kecerahan, intensitas cahaya matahari yang masuk ke dalam akan semakin besar (Nybakken, 1992).

Suhu perairan di lokasi penelitian berkisar antara $30-33^{\circ} \mathrm{C}$. Suhu mempunyai peranan penting dalam metabolisme bagi organisme perairan. Suhu perairan Sungai wedung berkisar antara $30-33^{\circ} \mathrm{C}$, dapat dikatakan bahwa suhu pada lokasi penelitian masih layak untuk kehidupan organisme perairan. Suhu air ratarata berkisar antara $24-32^{\circ} \mathrm{C}$ sehingga pada kisaran tersebut plankton dapat tumbuh dan berkembang biak dengan baik (Hutabarat dan Evans, 1986).

Kecepatan arus antara 0,07-0,29 m/s. Sedang menurut Effendi (2003), sungai dicirikan oleh arus yang searah dan relatif kencang dengan kecepatan berkisar antara $0,1-1,0 \mathrm{~m} / \mathrm{s}$. Kadar oksigen terlarut (DO) di Sungai Wedung selama penelitian berkisar antara 1,37-6,65 mg/l. Dilihat dari kandungan DO lebih besar dari $3 \mathrm{mg} / \mathrm{l}$ maka kehidupan ikan dan kebanyakan organisme lainnya masih dapat hidup dengan layak (Wardoyo, 1982).

Derajat keasaman $(\mathrm{pH})$ sangat berpengaruh pada adaptasi organisme perairan, $\mathrm{pH}$ dipegaruhi oleh aktivitas fotosintesis, suhu dan terdapatnya ion. Nilai $\mathrm{pH}$ pada lokasi penelitian berkisar antara $7-8$. Menurut Barus (2004), kisaran $\mathrm{pH}$ yang ideal untuk kehidupan organisme perairan adalah antara 7,5 - 8 . Berarti $\mathrm{pH}$ pada lokasi penelitian masih dalam kisaran yang baik untuk kehidupan organisme perairan. Kondisi perairan yang bersifat asam maupun basa akan akan menyebabkan gangguan metabolisme dan respirasi pada organisme. Disamping itu $\mathrm{pH}$ yang sangat rendah akan menyebabkan mobilitas berbagai senyawa logam berat yang bersifat toksik semakin tinggi.

Berdasarkan hasil pengukuran variabel penunjang dapat dilihat bahwa parameter fisika dan kimia masih berada pada batas normal. Oleh karena itu, rendahnya kandungan klorofil-a dimungkinkan berasal dari faktor-faktor lain seperti nutrien, limbah manusia disekitarnya dan lain-lain.

\section{Kelimpahan fitoplankton}

Pengamatan di lokasi penelitian di Sungai Wedung ditemukan 4 kelas fitoplankton. Keempat kelas tersebut terdiri dari Bacillariophyceae, Cyanophyceae, Clorophyceae dan Pypropyta yang ditemukan menyebar pada ketiga stasiun dengan jumlah genus yang bervariasi. Terdiri dari 11 genus Bacillariophyceae, 4 genus Cyanophyceae, 5 genus Clorophyceae dan 1 genus Pypropyta . Dari kempat kelas ini, kelimpahan sel fitoplankton yang mendominasi pada ketiga stasiun adalah kelas Bacillariophyceae dari genus Nitzchia sp dan Pleurosygma sp. Kelimpahan rata-rata fitoplankton pada masing-masing stasiun dapat dilihat pada gambar 4. 
Kelimpahan

(ind/l)

15000

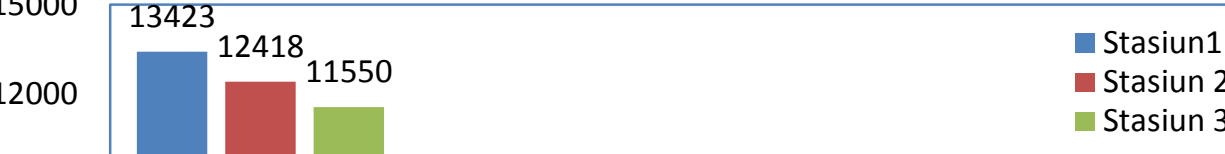

9000

6000

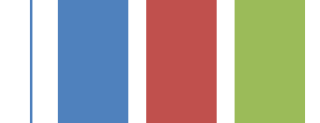

3000

0
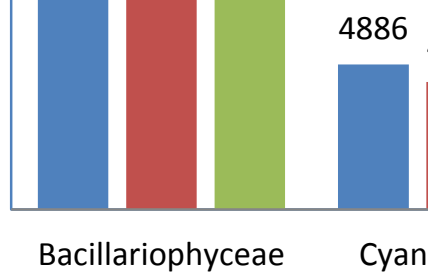

\section{5}

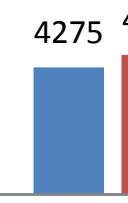

4699

4244

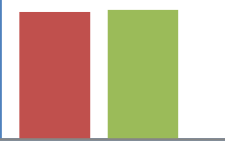

Cyanophyceae

Clorophyceae

$\begin{array}{lll}618 & 432 & 534\end{array}$

Genus

Gambar 4. Histogram Kelimpahan Fitoplankton

Kelimpahan fitoplankton yang didapatkan memiliki kelimpahan tertinggi pada stasiun I sebesar $23201 \mathrm{ind} / \mathrm{l}$, terendah pada stasiun III dengan kelimpahan sebesar $21841 \mathrm{ind} / \mathrm{l}$ dan pada stasiun III sebesar 20692 ind/l. Hal ini memberikan indikasi bahwa kegiatan pada lokasi 2 dan 3 (kawasan pasar dan TPI) memberikan kontribusi bagi peningkatan konsentrasi bahan nutrisi dalam air yang menyebabkan pertumbuhan fitoplankton yang optimal

Kelimpahan komunitas fitoplankton diperairan sangat berhubungan dengan kandungan nutrien seperti fosfat, nitrat, silikat, dan hara lainnya.Kandungan nutrien dapat mempengaruhi kelimpahan fitoplankton dan sebaliknya fitoplankton yang padat dapat menurunkan kandungan nutrien dalam air. Perubahan komposisi fitoplankton selanjutnya dapat mempengaruhi komposisi zooplankton dan komunitas plankton secara keseluruhan dalam suatu ekosistim (Pugesehan, 2010).

\section{Kesuburan perairan}

Kandungan Klorofil-a di perairan Sungai Wedung berkisar antara 0,94865 mg/l - 1,149152 mg/l dengan rata-rata $1,039863 \mathrm{mg} / \mathrm{l}$. Berdasarkan nilai rata-rata klorofil-a yang diperoleh, perairan Sungai Wedung tergolong kedalam perairan yang bersifat oligotrofik. Penggolongan tersebut berdasarkan status trofik perairan menurut Parslow et al., 2008 yakni kandungan klorofil pada kisaran $0-2 \mathrm{mg} / \mathrm{l}$ tergolong oligotrofik, 2 - $5 \mathrm{mg} / \mathrm{l}$ tergolong meso-oligotrofik, 5 - $20 \mathrm{mg} / \mathrm{l}$ tergolong mesotrofik, 20 - $50 \mathrm{mg} / \mathrm{l}$ tergolong eurotrofik dan $>50 \mathrm{mg} / \mathrm{l}$ tergolong hiper-eurotrofik.

\section{KESIMPULAN}

Berdasarkan hasil penelitian dapat disimpulkan bahwa:

1. Hasil analisis data klorofil menggunakan metode anova tersarang (nested anova) diperoleh nilai $\mathrm{P}$ untuk stasiun cukup besar sehingga tidak memberikan perbedaan yang nyata pada taraf kepercayaan $95 \%$. Akan tetapi perbedaan akan nyata pada taraf $90 \%$.

2. Hubungan antara klorofil-a dengan kelimpahan fitoplankton secara linear menunjukkan nilai keeratan yang tinggi dengan nilai koefisien korelasi sebesar 0,93 dan koefisien determinasi sebesar 0,8633 dimana $86 \%$ klorofil-a dipengaruhi oleh kelimpahan fitoplankton.

3. Berdasarkan nilai rata-rata klorofil-a yang diperoleh sebesar 1,039863 mg/l, perairan Sungai Wedung tergolong kedalam perairan yang bersifat oligotrofik.

\section{UCAPAN TERIMA KASIH}

Ucapan terima kasih ditujukan kepada Drs. Ign. Boedi Hendrarto, M.Sc, Ph.D dan Dr. Ir. Max Rudolf Muskananfola, M.Sc atas bimbingannya dalam penyusunan penelitian ini.

\section{DAFTAR PUSTAKA}

APHA. 1992. Standard Methods For The Examination of Water and Waste Water $18^{\text {th }}$ Edition. APHA, AWWA, WEF. Washington DC.

Barus, T.A. 2004. Fakto-Faktor Lingkungan Abiotik dan Keanekaragaman Plankton sebagai Indikator Kualitas Perairan Danau Toba. Jurnal Mahasiswa dan Lingkungan, XI: 61-70.

Effendi, H. 2003. Telaah Kualitas Air. Penerbit Kanisius. Yogyakarta.

Hadi, S. 1998. Metodologi Research Jilid IV. Penerbit Andi Offset. Yogyakarta. 
Hermawan, W. 2007. Pengantar Metodologi Penelitian Buku Panduan Mahasiswa. PT. Gramedia Pustaka Utama. Jakarta.

Hutabarat, S. dan S. M. Evans.1986. Kunci Identifikasi Zooplankton. UI Press. Jakarta.

Nybakken, J. M. 1992. Biologi Laut: Suatu Pendekatan Ekologis (diterjemahkan oleh H. M. Eidmar, Koesbiono, D. G. Bengen, M. Hutomo dan D. Sukardjo). Gramedia. Jakarta.

Parslow, J., J. Hunter and A. Davidson. 2008. Estuarine Eutrophication Models. Final Report Project E6 National River Health Program. Water Services Association of Australian Melbourne Australia. CSIRO Marine Research. Hobarth, Tasmania.

Parsons, T. R., M. Takeshi and B. Hagrave. 1984. Biological Oceanographic Processes. Third Edition. Oxford. Pergamon Press. Great Britain.

Pugesehan, D. J. 2010. Analisis Klorofil-A Fitoplankton (Produktivitas Primer) di Perairan Pantai Netsepa Kabupaten Maluku Tengah. Politeknik Perdamaian Halmahera. Tobelo. J. Agroforestri, V (4): 272278.

Sachlan, M. 1982.Planktonology. Fakultas Peternakan. Universitas Diponegoro. Semarang.

Sukadi. 1999. Pencemaran Sungai Akibat Buangan Limbah dan Pengaruhnya terhadap BOD dan DO. Institut Keguruan dan Ilmu Pendidikan. Bandung.

Tambaru, R. 2008. Dinamika Komunitas Fitoplankton dalam Kaitannya dengan Produktivitas Primer di Perairan Maros, Sulawesi Selatan. [Disertasi]. Sekolah Pascasarjana. IPB. Bogor.

Walpole, R. E. 1995. Pengantar Statistika. Alih Bahasa: Ir. Bambang Sumantri. Edisi ke-3. PT. Gramedia Pustaka Utama. Jakarta.

Wardoyo, S. T. H. 1982.Pengelolaan Kualitas Air Pusat Studi Pengelolaan Sumber Daya Lingkungan. IPB. Bogor.

Widyorini, N. 2009. Pola Struktur Komunitas Fitoplankton Berdasarkan Kandungan Pigmennya di Pantai Jepara. Jurnal. Program Studi Manajemen Sumberdaya Perairan Jurusan Perikanan Universitas Diponegoro. Semarang. J. Saintek Perikanan IV (2): 69-75. 